ESCUDERO, Camila. O Rio de Janeiro dos Imigrantes. Páginas de uma cidade de muitos povos, 1. ed., Rio de Janeiro: E-papers, 2016.

\title{
Cidade maravilhosa, terra que a todos seduz
}

\section{Maria Inês Amarante ${ }^{1}$}

É inegável que o Rio de Janeiro é um dos mais belos cenários que se oferece aos visitantes de todos os cantos do mundo. Fonte de inspiração de romances, músicas ou paisagem-modelo para artistas de todas as tendências, a cidade completou 450 anos, em 2014, e foi homenageada com a pesquisa da autora Camila Escudero.

A obra O Rio de Janeiro dos Imigrantes. Páginas de uma cidade de muitos povos, publicada em 1a. Edição pela E-papers-RJ, em 2016, tem como proposta apresentar a diversidade cultural por meio da imprensa imigrante carioca. Ela oferece assim um panorama geral sobre a confluência étnica e linguística das diversas comunidades estrangeiras que integram a população da antiga capital do país e se incrementa entre o final do século XIX e início do século XX, após a abolição.

Jornais e revistas de todos os matizes e idiomas traduzem o desejo de integração de pessoas que escolheram viver ali, ao mesmo tempo em que revelam suas impressões e reivindicações enquanto cidadãos partícipes de uma cidade que cresceu e se transformou. O livro é organizado em capítulos que trazem uma breve descrição histórica das publicações de cada nacionalidade e concluem com curiosidades, como dados estatísticos, socioculturais, personagens de destaque, pautas noticiosas etc. Assim vislumbramos um Rio de Janeiro multifacetado.

O marco inicial é 1765, quando surge o jornal italiano La Croce del Sud. Mas a autora considera três etapas evolutivas da imprensa carioca que abrange os anos 1800 até a atualidade, quando as produções se consolidam.

Desde o século XVI marcando domínio colonial em todo o país, os portugueses fundaram várias associações e centros culturais e contribuíram em periódicos brasileiros.

1 Professora adjunta da Universidade Federal da Integração Latino-Ameninaca (Unila) Instituto La tino-Americ ano de Arte, Cultura e História. Email: inesa marante@gmail.com. 
Em 1836, lançam o jornal Liberal Lusitano, que inaugura uma série de outras publicações que atravessaram o século $X X$ até o atual. Os destaques são os jornais $A$ Messe, criado em 1860, e o Portugal em Foco - um Jornal Luso-Brasileiro, ainda em circulação. Além dos periódicos, a revista Lusitânia circulou na década de 1930 com um bordão nacionalista "da aproximação luso-brasileira e de propaganda de Portugal - Pela grandeza da Pátria - Pela eternidade da raça" (p. 12).

Os espanhóis - em sua maioria provenientes da Galícia - faziam críticas diretas à exploração dos portugueses por meio de jornais como A Gallegada - Folha Reaccionaria (1883-1886). No início do século XX lançam El Correo Gallego, em espanhol, distribuído aos assinantes. Uma notícia curiosa que consta de seus registros é o crime cometido por um delegado de polícia contra um cidadão galego, antevendo os acontecimentos que se tornariam corriqueiros na cidade.

A comunidade italiana que se instalou no Rio, lança, em 1875, o jornal La Gazzetta Italiana Del Brasile, em italiano e, em 1885, o L'Italia - Organo degl'interesse ItaloBrasilliani, que sobrevive até 1889. Os italianos foram os pioneiros na distribuição e vendas de periódicos, tendo criado uma cooperativa para tal atividade.

Consta que os franceses escreviam jornais em língua materna desde 1820. Mas na segunda metade do século XIX publicaram La Gazette du Brésil; Le Nouvelliste e o Courrier du Brésil e até um jornal de tendência socialista, Le Sud-Américain. Pioneiros no lançamento da moda que se expunha nas vitrines da Rua do Ouvidor, também o foram na arquitetura e na gastronomia.

Muitos foram os imigrantes que se destacaram no comércio, como os árabes - da comunidade sírio-libanesa -, que prosperaram no ramo têxtil e de armarinhos. Parte dessa história encontra-se na revista SAARA Informa, fundada em 1962. Mas uma geração de intelectuais publicou, de 1933 a 1953, a Revista Nova Andaluzia, um dos 60 títulos lançados na cidade.

A numerosa comunidade judaica ${ }^{2}$ lançou, em 1916, A Columna - Órgão de Interesses do Povo Judeu no Brasil, periódico mensal cuja ideia era a divulgação cultural e a união de suas diversas associações em um Centro Israelita. Inúmeros informativos surgidos de 1929 até 2009 se servem da língua portuguesa para unificar os judeus de origens diversas que não dominam o ídische.

\section{5 mil fa mílias.}

Revista Pauta Geral-Estudlos em J omalismo, Ponta Grossa, vol. 4, n.1, p.134-137, Jan/J un 2017. 
Já os alemães, que introduziram no país bebidas populares como a cerveja e o chope, fundaram a mais antiga agremiação estrangeira no ano de 1821: a Sociedade Germania. Publicaram, em língua materna, periódicos como o Der Deutsche Einwanderer e o Der Deutshe Beobachter, desde 1853, aos quais se agregam informativos como o Deutsches Tageplatt (de 1915 a 1917). O Boletim Informativo dessa sociedade, bimestral, existe há mais de 12 anos.

Do leste europeu, os poloneses se destacam pela revista virtual quadrimestral Polonia Carioca, ${ }^{3}$ publicada pela Polônia Sociedade Beneficente do Rio de Janeiro.

As ditaduras instaladas no continente latino-americano, as revoltas políticas, a precarização econômica e as catástrofes naturais trouxeram para cá novos imigrantes, como os bolivianos que, nos anos 1950, se concentraram entre o Rio e São Paulo. Os grupos politicamente conservadores e privilegiados do início deram lugar a numerosos estudantes, trabalhadores manuais, músicos etc. A comunidade chilena, cuja maior afluência ocorreu durante o regime de Pinochet, desde 1937 lança publicações como a Revista de Intercâmbio Chileno-Brasileiro e o Boletim Camara de Commercio ChilenoBrasileira, de 1944.

Os haitianos começam a chegar em 2010, após o terremoto que destruiu grande parte da ilha caribenha trazendo desolação e ameaça de doenças.

Os novos imigrantes, tal qual os de antigamente, fundam círculos e utilizam formas mais rápidas de comunicação entre suas comunidades e aquela que os acolhe trazidas pela era digital. Um dos exemplos é a Revista Virtual Nativos - La Revista de los peruanos en Brasil, em espanhol. Surgida na década de 1960, abrange a imigração peruana em todo o país e oferece ${ }^{4}$ informações relevantes para a comunidade em geral, além da divulgação da cultura sulamericana - servindo de ponto de encontro de todos.

A comunidade lusófona se ampliou com a chegada dos angolanos nos anos 1980. O Consulado de Angola no Rio publica institucionalmente o Jornal da Comunidade Rio Kwanza e Notícias de Angola (1994). Há igualmente registros de comemorações e

\footnotetext{
3 http://www.brasilia.msz.gov.pl/pt/c/MOBILE/acontecimentos/polonia_carioca

4 https://www.fa cebook.com/Revista-Na tivos-186476838062568/about/?ref=page_intemal
}

Revista Pauta Geral-Estudlos em J omalismo, Ponta Grossa, vol. 4, n.1, p.134-137, Jan/J un 2017. 
intercâmbios culturais com o Brasil e informativos para o público angolano da cidade ${ }^{5}$, como o Atualidade Angolana, surgido em 1987 e o Angola Hoje, de 2001.

Outras imigrações provenientes da África foram registradas pela mídia impressa, como a dos congoleses, a partir de 2003. Da Ásia, a chegada dos primeiros chineses ocorre em 1888.

A obra nos faz refletir sobre o quanto de história há nos registros informativos e como é relevante esta diversidade de grupos que compõem a sociedade brasileira e que aqui se organizaram para criar seus próprios meios de comunicação e de preservação cultural. A maioria dos imigrantes pode realizar o sonho de trabalho e vida digna compartilhando seus saberes, valores e crenças. Todos foram acolhidos por uma cidade de grande beleza, cujo símbolo maior é o Cristo Redentor de braços abertos... Contudo, atualmente, a recíproca não é verdadeira, pois grande parte desses países se esqueceu da solidariedade encontrada no sul, transformando a imigração em uma "tragédia sem fronteiras", como lembra Ventura (2015). Em que pesem as ameaças de um Estatuto do Estrangeiro, o Rio de Janeiro de cada um dos imigrantes continua sendo a terra de todos...

5 Pelo recenseamento de 2015, citado pela autora, estima-se a presença de 1.480 angolanos no Brasil, dos quais $1 / 3$ vivem no Rio de J aneiro. 